\title{
UDC 378.147.811.111
}

\section{Sophiya Yu. Nikolaeva}

Doctor of Pedagogical Sciences, Professor, Head of the Department of

Foreign Languages Methodology Teaching and Information and Communication Technologies

Kyiv National Linguistic University, Kyiv, Ukraine

ORCID ID 0000-0003-2522-2059

nikolaeva.ku@gmail.com

\section{Kateryna O. Shevelko}

$\mathrm{PhD}$ of Pedagogical Sciences,

Assistant Professor of the Department of the English Language, Translators' and Interpreters' Faculty

Kyiv National Linguistic University, Kyiv, Ukraine

ORCID ID 0000-0001-7008-843X

kateryna.shevelko@gmail.com

\section{Yana H. Fabrychna}

$\mathrm{PhD}$ of Pedagogical Sciences,

Assistant Professor of the Department of the English Language, Translators' and Interpreters' Faculty

Kyiv National Linguistic University, Kyiv, Ukraine

ORCID ID 0000-0003-1009-6598

yanafabrichnaya@gmail.com

\section{ICT-SUPPORTED EXTRA-CURRICULAR ACTIVITIES FOR UNIVERSITY STUDENTS MAJORING IN TRANSLATION STUDIES}

\begin{abstract}
In the context of the reformation of the higher education in Ukraine the preparation of translators and interpreters requires new approaches to the process of teaching and learning. It presupposes the implementation of ways and forms aimed at active rather than passive learning, an increased sense of academic autonomy, development of motivation, responsibility and accountability in acquiring profession-specific knowledge, skills, communicative abilities and attitudes as well as interdependence and mutual respect between the academic teacher and the student.

The authors of the article argue that the language tuition to students majoring in translation studies contributing to the overall development of their professional competence of intercultural mediators can be carried out in the form of extra-curricular activities via information and communication technology tools.

With respect to the results of the grounded study of current tendencies, achievements and problems, valuable experience and outcomes related to the issue under consideration, the paper reflects on two extra-curricular activities, their stages, aims, objectives and tasks performed; analyses their importance and efficiency in promoting students' autonomy and responsibility; outlines the role and the functions of information and communication technology tools used.

The English Speaking Club involves specially arranged meetings intended to provide practising English autonomously outside the classroom context. Participating in conversations with a native speaker students have the opportunity to improve their vocabulary, grammar, pronunciation skills, enrich their background knowledge of traditions and culture of the English-speaking countries as well as overcome psychological barriers while expressing personal views and ideas.

Translation and Voice Over Recording Studio is organised as a project activity tailored to initiate student translators and interpreters to the real workflow of a project team specialising in translation of different types of audio and video texts in the English language into Ukrainian and their further voice over recording. Performing roles of translators, proofreaders, editors, voice-over artists and sound directors, the participants have the opportunity to practically implement knowledge, skills and communicative abilities obtained while learning profession-specific subjects at the university, developing and improving translation and interpretation skills in particular. Specially selected information and communication technology tools provide the efficient organisation of the Club's and Studio's work.
\end{abstract}

Keywords: extra-curricular activities; information and communication technology tools; ICTs; academic students majoring in translation studies. 


\section{INTRODUCTION}

With the growth of the Internet and the increasing use of computers and mobile gadgets at home and in educational institutions online support in language learning is steadily developing its popularity. While the idea of language learning through computer assisted language tools is not new, informal learning of English by means of extra-curricular activities can also benefit from the use of online technology combined with face-to-face teaching [1]. Nevertheless, the implementation of such a form and tools of language education requires careful consideration as for the place and the way of their utilisation.

The problem statement. Kyiv National Linguistic University (KNLU), one of the leading educational establishments in Ukraine, actively participates in the process of reformation of higher education launched in 2014 [2], the major demands of which are the implementation of the student-centered approach to the process of teaching and learning and the development of students' academic autonomy. In the pages that follow, with respect to requirements mentioned above such forms of ECAs as the English Speaking Club and the Translation and Voice Over Recording Studio organized at the Faculty of Translators and Interpreters at KNLU are offered to benefit to reliance of pre-service translators and interpreters on active rather than passive learning, an increased sense of autonomy, motivation, responsibility and accountability in acquiring profession-specific knowledge, skills, communicative abilities and attitudes as well as interdependence and mutual respect between the academic teacher and the student. Information and communication technologies (ICTs) are supposed to provide the efficiency of organizing and functioning of the suggested ECAs and contribute to the reflexive approach to the teaching and learning process on the part of both academic teachers and students.

Analysis of recent research and publications. The review of recent research and publications on the issue under discussion covers literature published from 2003 to 2019 and comprises the academic articles and conference papers related to the issues of implementing ECAs and utilizing ICTs in teaching and learning in higher education, professional foreign language education in particular.

The findings concerning ICTs show that researchers debate on various impacts of ICTs on the development of higher education: the role of ICTs in transforming the process of teaching and learning in terms of content, ways and methods, learning place and time (R. Oliver, 2003); benefits and limitations of different design principles and forms of elearning and online assessment (R. Benson and C. Brack, 2010); issues of access, equity, management, efficiency, pedagogy and quality of the integration of ICTs in various aspects of higher education (A. Mandal and J. Mete, 2012); the purpose of technology interventions and the approaches to enhance the learning experience (A. Kirkwood and L. Price, 2014).

Focusing on the problem of digital competence of student teachers of foreign languages, the study by N. Hockly (2013) describes digital technologies a language teacher needs to be able to effectively make use of in the language classroom, while the Ukrainian author O. Bigych (2010) presents the information and communication portfolio for a foreign language teacher. A number of researchers refer to the application of ICTs to the process of teaching and learning aimed at the development of the professional competence of students majoring in philology (N. V. Sorokina and L. G. Smovzhenko, 2018; O. V. Malykhin and V. A. Karpiuk, 2018), foreign languages teaching (L. S. Shevchenko and A.I. Kryzhanovskyi, 2018; N. V. Maiier and T. I. Koval, 2018; O. B. Bigych and D. A. Rusnak, 2019; N. F. Borysko, 2019; A. V. Dolyna, 2019;) and translation studies (I. M. Drobit and N. V. Rak, 2013; O. Matsiuk, 2014; Yu. I. Bets, M. H. Palahniuk and V. P. Yurkova, 2016).

There are papers reporting on the experience of academic teachers in using a particular technology in a specific area or for specific teaching/learning purposes: design and 
development of multimedia educational presentations in foreign languages teaching in general (A. Klymenko, 2013); teaching speaking and writing skills to student teachers of English (B. Kuksa, 2010); Facebook as the means of teaching writing to student teachers of English (M. S. Hlazunov, 2013); effects of employing ICT on listening skills of learners of English (R. Metruk, 2019); educational computer programme for teaching fiction reading (A.S. Drach, 2018); cloud computing for producing and sharing learning objects and activities, MOOCs and learning analytics platforms for a writing course, games and gamification as a training and motivation tool (S. Briggs, 2013); social networks for creating learning content engaging students and observing and coordinating their work (O. P. Pinchuk, 2016); features of blog in teaching French to future philologists (H. F. Dranenko and D. A. Rusnak, 2013); selection of online learning materials for teaching reading (I. V. Korejba, 2009) and speaking (H. Podosynnikova, 2013); collaborative digital video project in a technological learning environment for fostering learner autonomy in English for science (C. A. Hafner, 2011); benefits of electronic portfolios in the language classroom (S. Y. Ali, 2005); use of ICT tools in the process of introducing project work in the pre-service translators' training (I. Sekret, 2017).

The analysis of the works by Ukrainian and foreign scholars also reveals a great attention to ECAs as a form of university education. Defining the idea, functions and the structure of ECAs the following papers suggest selected forms of ECAs to be efficiently performed in teaching university students (M. Bahdi, 2014; G. P. Ivanova and O. K. Logvinova, 2017; M. O. Kuts, 2017). Besides this, the types of ECAs university students specialising in different fields prefer and disapprove of have been studied (G. P. Ivanova and O. K. Logvinova, 2017; V. Ivanova and K. Mertins and S. Kaftasev, 2017).

Although no strong association between participation in extracurricular activities and students' academic performance in general has been found (N. Arranz, F. Ubierna, M. F. Arroyabe, C. Perez, J. C. Fdez. de Arroyabe, 2017; H. D. Hunt, 2007; S. F. Ismail, 2014; P.-S. Seow, 2014), many researchers claim that there are positive effects of ECAs on developing soft skills of students and their further professional training due to voluntary engagement, non-formal and interactive nature of this kind of work and higher social activity of its participants (C. Cordea, 2014; I. B. Zarubinska, 2011; G. P. Ivanova, O. K. Logvinova, 2017; V. Ivanova, K. Mertins, S. Kaftasev, 2017; V. Kovalenko, 2014; E. Massoni, 2011).

Different investigations and research projects have shown the correlation between ECAs and teaching English as a foreign language. Providing a relaxed learning environment ECAs have proved to improve students' academic oral performance and overcome some of their psychological speaking problems (M. Bahdi, 2014; M. V. Kuimova, D. A. Polyushko, 2017). Despite the significant contribution of language-related ECAs to language learners' motivation by providing them with an additional environment for language practice, problems in organising such activities were also identified (V. Makarova, A. Reva, 2017).

A number of researchers suggest providing ECAs via ICTs. Discussing ECAs as a kind of pedagogical technology, M. Kuts has developed an educational package to support teaching English to technical university students through ECAs on the learning platform Moodle (M. O. Kuts, 2017). N. Rashevska explores the utilisation of ICTs in blended learning, where ECAs are an integral part of high quality university education and a valuable kind of support in student-teacher cooperation within a unitary educational information environment (N. V. Rashevska, 2011). Dwelling on the impact of ICTs on the curriculum that should face the requirements of current students, scholars refer to the instructional technology that helps both teachers and students to focus on a certain educational goal rather than getting fun from participating in ECAs (M. Teimoornia, F. Hamidi, S. M. R. I. Jomehc, S. Foroozesh-nia, 2011).

The coverage of journal articles and conference papers revealed a considerable amount of academic investigations on the use of ICTs and organising the teaching process via ECAs 
in the professional language education. However, the issue of ICTs use in extra-curricular activities for students majoring in translation studies has not received enough attention of researchers and practitioners so far.

The article's goal is to offer the forms of ECAs aimed at the development of the profession-specific knowledge, skills, communicative abilities and attitudes of students majoring in translation studies, describe the stages of the activities, aims, objectives and tasks performed, analyse their efficiency in promoting students' autonomy and responsibility, outline the role and the functions of ICTs used.

\section{RESEARCH METHODS}

To achieve the goals of this study the following research methods were used: critical review of recent publications on use of ECAs and ICTs in professional language education intended for finding out current tendencies, achievements and problems, valuable experience and outcomes related to the issue under discussion; analysis of key documents aimed at considering and incorporating principles of higher education [2], [3] as well as recommendations and requirements to the translators' competence [4], [5]; survey on the participants' needs, interests, preferences, attitudes, problems, self-reflection and feedback; observation of the participants' involvement in the activity, their interaction, progress and achievements.

\section{THE RESULTS AND DISCUSSION}

\section{The English Speaking Club}

One of the ways to put the idea of ECAs for student translators and interpreters into practice is to organise an English Speaking Club. These are specially arranged meetings where students can get acquainted with traditions and culture of English-speaking countries with a native speaker who leads the conversations.

The main aim of this form of ECAs is to improve students' communicative competence, which is indisputably beneficial for their professional training as prospective translators and interpreters. The objectives of the Club are to provide the students with an opportunity to use and practise English autonomously outside the classroom context, enrich their knowledge of vocabulary, grammar and socio-linguistic aspects of the language, improve the pronunciation skills in a natural speaking environment and to help them overcome psychological barriers while expressing personal views and participating in conversations in the English language. The aim and objectives are reached due to the voluntary basis of the club, meeting students' and teachers' requirements concerning topics discussed at the meetings and specially selected ICTs that provide successful organisation of the Club's work. Among possible ICTs suggested by researchers to cover the needs of ECAs [6], [1], [7] we focused on the tools involved in the compulsory stages of the Club's work - preparation, managing and monitoring. At all the stages the club supervisor(s), native speaker(s) and students are active participants of the Club in different kinds of activities mentioned below.

The preparation stage requires careful examination of students' communication needs, their personal interests and the minimum language fluency requirements for the participants to freely cope with the communicative tasks at a particular Club meeting. At this stage we regularly create a questionnaire in Google Forms for the supervisor, the native speaker, the students and their course lecturers to suggest topics for further meetings and vote for the Club agenda. Thus, everyone can contribute with the lists of topics they consider essential. 
According to the survey, students usually request discussions on current social matters or psychological problems the youth face, their course lecturers prefer including the topical content that agrees with the existing syllabi in language practice the prospective participants follow in their curricula activities, while the supervisor and the native speaker can suggest discussing events or specific socio-cultural phenomena in the context of different countries or their regions.

The next step of preparation is registration of the agreed topic in the Google Sheets file where the participants fill in their names opposite the chosen dates and topics in order to express their intention to participate in the Club. Figure 1 presents the form that includes the participants who attended the meetings held in September-December 2018 and agreed to expose their personal data in this article.

Besides, this stage suggests selecting or/and designing preparatory tasks which aim at students' better readiness for speaking activities in terms of language and background knowledge. These include topical glossaries, online exercises in relevant vocabulary and grammar, lists of questions worth cogitating on, articles, videos and podcasts. The process of selection of multimedia resources can be performed according to the criteria defined by O. Martynenko [8].

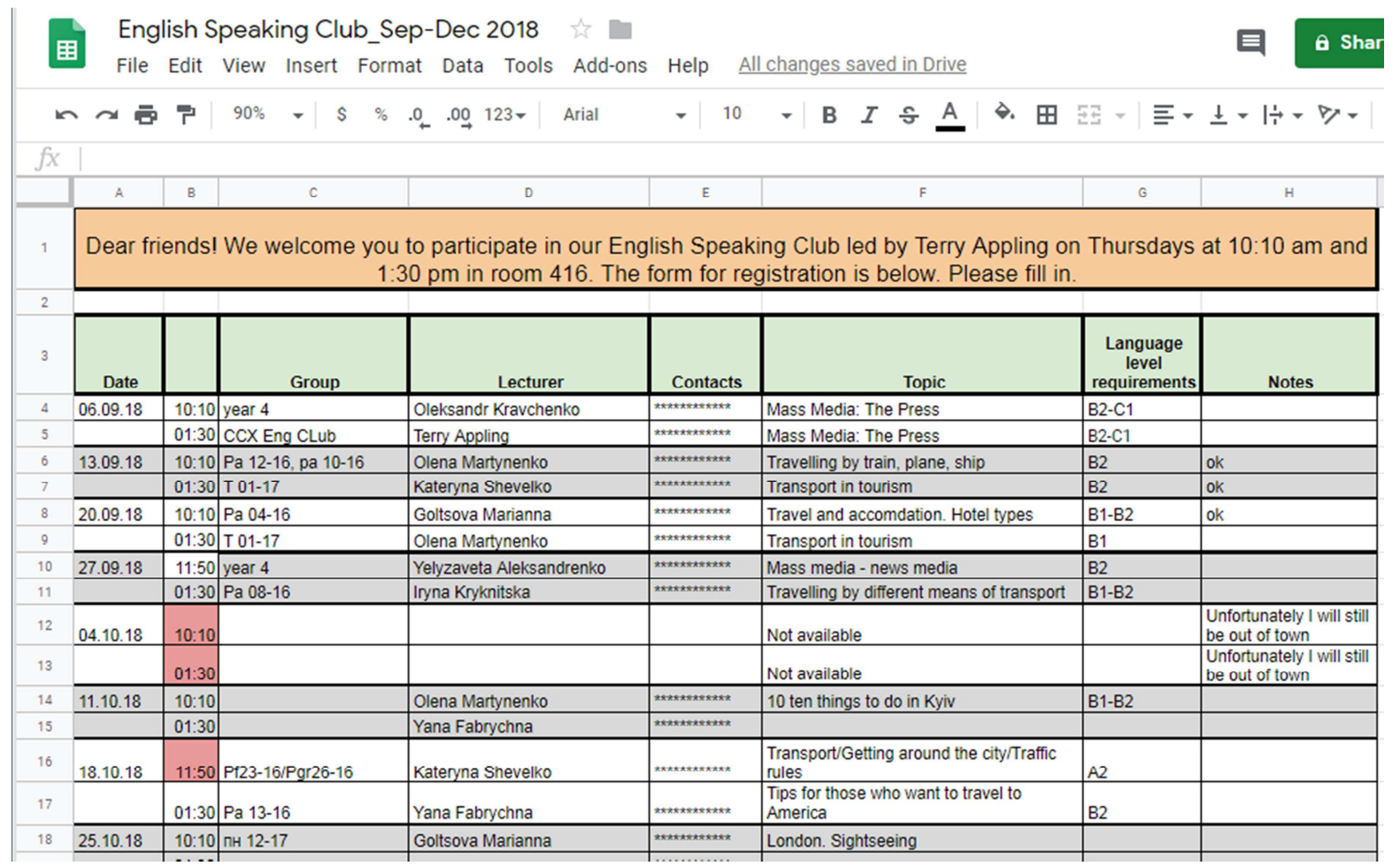

\section{Figure 1. A screenshot of the Google Sheets registration form}

The managing stage generally intends for involving students in the Club discussions and holding the meetings. It should be preceded by deciding on the frequency, the time, the location of the sessions and the size of group. As the Club is held on a regular basis with possible variations in the time and venue we registered a Facebook page to cover the need for advertising the Club activities, announcing the following events, issues for the upcoming discussions and the external links to the resources meant for students' preparation. Being the most popular social network in Ukraine that is used by $45.21 \%$ of Ukrainians [9] Facebook provides a great learning and teaching environment as well as an efficient administrative tool [10]. In terms of this, the moderator of the Club's page posts status updates, photos illustrating the upcoming discussions and the ones reporting the students' activities during the 
recent session of the Club, fills in and updates the profile information if it changes. Both the supervisor and the native speaker can make reposts of the coming events on their personal pages engaging more students and lecturers to get acquainted and interested in the work of the Club. At the managing stage the Facebook page also provides students with language support in the form of links to external files, pages or multimedia resources complementing their knowledge on the topic of the upcoming meeting as it was mentioned above.

The monitoring stage helps to examine the effectiveness of the work done by the Speaking Club. Such routine gives an opportunity to consider strengths and weaknesses in both organisation and content of this ECA. It also helps to decide on areas for improvements and carry them out in planning and holding further activities. At this stage all participants of the meeting are asked to leave commentaries expressing their impressions under the post in Facebook where the meeting has been announced. Owing to such regular feedback the supervisor and the native speaker can figure out if extra support is needed. It is also possible to create a Google Form questionnaire at the end of every semester for all the participants to evaluate the way particular components of the Club's work were realised.

\section{Translation and Voice Over Recording Studio}

Another extra-curricular activity for students of the translation studies faculty is organized as a project activity [11] in the form the Translation and Voice Over Recording Studio (TVORS). Aimed at the practical implementation of knowledge, skills and communicative abilities obtained while learning profession-specific subjects at the university, developing and improving translation and interpretation skills [4], [5] in particular, this ECA consists of four stages [11]: I - motivation, II - planning, III - execution, IV - evaluation. Each is characterized by a distinct set of activities, is of equal importance and contributes to the overall success.

Stage I (motivation) is the start of the project and its goal is to familiarize the participants with the concept, purposes and realization of the TVORS. It also includes the survey on students' interests in styles, genres and types of audio or video texts for further translation and voice over recording. According to the survey conducted in Google Forms, among students' preferences are public speeches, television series and animated films. During the motivation stage students form project teams, choose names, symbols, mottos etc - since 2015 there have been three project teams, each specialising in particular genres: Big Bang Studio (sitcoms and public speeches), KРUПA (cartoons and comedy television series) and Serial Killers (superhero web television series).

Stage II (planning) involves choosing the project manager, distributing social roles and responsibilities for translators, proofreaders, editors, voice-over artists and sound directors, discussing equipment and ICT tools needed.

Stage III (execution) is the main phase during which the participants perform the actual work. It includes distribution of the original text among the students for translation, proofreading and editing. The ICT tool utilised in the process is Google Docs, where the translators make scripts, compile glossaries of lexical units and terms, which helps provide lexical and terminological consistency of the target text. The Google Docs tool also allows them to share their pieces of translation for proofreaders and editors to perform their job: share results of informational search, make amendments, insert comments and references. Then the team members discuss versions of the translation, ways of rendering nationally and culturally biased lexicon, ways of the translation improvement, and the necessity of localisation, approve its final version. The project manager organises and controls the workflow which involves tasks delegation, schedule adjusting if necessary, forms and terms of the final product presentation. Efficiency of the project manager's job is provided by the 
tools of Google Drive and popular messaging applications Viber, WhatsApp or Google Hangouts. The next part of the stage of execution is voice over recording during which translators, proofreaders, editors, their teachers, friends and even relatives become voice-over artists and sound directors. This process requires a good recording environment (we made up an abandoned university radio studio), a computer, audio software such as Audacity, an audio interface, headphones, a microphone and a pop shield.

Stage IV (evaluation) involves reporting and presentation of the outcomes. Via Google Docs, Google Slides and Powerpoint the team creates the portfolio of the project which includes a script of the original text, translations at different stages of their creation, a glossary, a voice over recorded video or audio. While presenting the results of their work the participants analyse their activity, evaluate the process and the outcomes, identify to what extent they have realised the goals, assess the strategies and ways of their realisation. While evaluating their activity the students reflect on practical implementation of knowledge, skills, communicative abilities and attitudes obtained during practical classes at university as well as during TVORS activities. The results of the feedback discussion of what the students have learnt while working on the translation and voice over recording projects are presented in Table 1.

Table 1

The Results of the Feedback Discussion

\begin{tabular}{|c|c|c|}
\hline Project Team & Name of the Project & Feedback \\
\hline $\begin{array}{l}\text { Big Bang } \\
\text { Studio }\end{array}$ & $\begin{array}{l}\checkmark \text { the TV sitcom The Big } \\
\text { Bang Theory (the pilot } \\
\text { episode) } \\
\checkmark \text { Barak } \\
\begin{array}{ll}\text { Inspirational } & \text { Obama's } \\
(2008) & \text { Speech }\end{array} \\
\end{array}$ & \multirow{3}{*}{$\begin{array}{l}\text { knowledge of American students' slang, idioms, } \\
\text { scientific terminology (physics), proper names, } \\
\text { abbreviations and ways of their rendering into } \\
\text { Ukrainian, how to plan and organise translation } \\
\text { activity, Google Drive tools features; skills in } \\
\text { making a script, text proofreading and editing, } \\
\text { translating poetry and localisation, sound } \\
\text { recording, video montage, acting, improvisation, } \\
\text { working in a team, organising working space; } \\
\text { abilities and readiness for self-study and self- } \\
\text { development, to plan working hours, follow } \\
\text { agreements, overcome difficulties, switch over } \\
\text { from one language / culture into the other, find } \\
\text { necessary information, develop strategies for } \\
\text { solving problems, be involved in a team work, } \\
\text { take the responsibility for accuracy and quality } \\
\text { standards of translation, evaluate personal } \\
\text { contribution. }\end{array}$} \\
\hline КРUПА & $\begin{array}{l}\checkmark \text { Part of the animated film } \\
\text { Rapunzel } \\
\checkmark \text { the comedy TV series } \\
\text { The Last Man on Earth } \\
\text { (seasons } 1 \text { and 2) }\end{array}$ & \\
\hline Serial Killers & $\begin{array}{l}\checkmark \text { the superhero TV series } \\
\text { The Flash (season 1, } \\
\text { episode 1) } \\
\checkmark \text { the superhero TV series } \\
\text { Jessica Jones (season 1, } \\
\text { episodes } 1 \text { and 2) }\end{array}$ & \\
\hline
\end{tabular}

Teacher's observation of the students' participation in this ECA and the results of the feedback discussion revealed that pre-service translators and interpreters demonstrated such attributes of their autonomy as motivation, awareness, interaction, independence in making decisions, willingness to take control of the workflow, reflection, evaluation and selfevaluation, strategic thinking. In the context of students' autonomy within the TVORS the academic teacher is supposed to be chief manager, proofreader, editor, consultant, guide and supervisor who encourages and monitors the students' activity, helps overcome difficulties, and creates favourable conditions aimed at supporting students' autonomy and creative potential. 


\section{CONCLUSIONS AND PROSPECTS FOR FURTHER RESEARCH}

In the article we reflected upon two ICT-supported ECAs aimed at the development of the profession-specific knowledge, skills, communicative abilities and attitudes of students specialising in translation studies; described the stages of the activities, aims, objectives and tasks performed; analysed their efficiency in promoting students' autonomy and responsibility; outlined the role and the functions of ICTs used.

The outcomes of the study reveal that students participating in both English Speaking Club and Translation and Voice Over Recording Studio considerably improved their English language communicative competence, implemented knowledge, skills and communicative abilities obtained while learning profession-specific subjects at the university, developed and improved their translation and interpretation skills owing to specially organised meetings with a native speaker as well as performing the translation of sitcoms, cartoons, public speeches, comedies, and superhero TV series from English into Ukrainian and their further voice over recording.

Students' involvement in the organisation of the activities facilitated the development of their motivation, awareness, independence in making decisions, willingness to take control of the workflow, reflection, evaluation and self-evaluation, use of an adequate strategy, which gives the grounds to confirm the efficiency of the suggested ECAs in promoting students' autonomy.

Such information and communication technology tools as Google Forms, Google Sheets, Google Docs, messaging applications Viber, WhatsApp, and social network Facebook appeared to be convenient tools for organisation, communication and support of the activities and efficient for establishing connection between all participants at every stage of the suggested above ECAs.

The issue for possible further study is the challenges teachers and/or students face while performing their work in ECAs through computer assisted tools. Besides, designing ICTsupported ECAs for university students majoring in other professions in the form of reading, cooking or gaming clubs might also be worth consideration.

\section{REFERENCES (TRANSLATED AND TRANSLITERATED)}

[1] D. Toffoli and G. Sockett, "University teachers' perceptions of Online Informal Learning of English (OILE)", Tandfonline.com, 2013. [Online]. Available: https://www.tandfonline.com/doi/full/10.1080/095 88221.2013.776970. Accessed on: Feb. 09. 2019. (in English)

[2] Stratehiia reformuvannia vyschoi osvity v Ukraini do 2020 roku. (Proekt). [Strategy of reformation of the higher education in Ukraine till 2020. (Draft)], 2015. [Online]. Available: http://search.ligazakon.ua/1_doc 2.nsf/link1/NT1109.html. Accessed on: Feb.02.2019. (in Ukrainian)

[3] UNESCO, "Information and communication technology in education. A curriculum for schools and programme for teacher development. Division of higher education", 2002. [Online]. Available: http://unesdoc.unesco.org/images/0012/001295/129538e.pdf. Accessed on: Feb.02.2019. (in English)

[4] EMT Expert Group, "Competences for professional translators, experts in multilingual and multimedia communication”, 2009. [Online]. Available: http://ec.europa.eu/dgs/translation/programmes/emt/key_doc uments/emt_compet ences_translators_en.pdf. Accessed on: Feb.02.2019. (in English)

[5] National Occupational Standards in Translation, CILT, the National Centre for Languages, 2007, 40 p. (in English)

[6] N. Rashevska, Mobile information-communication technologies of teaching advanced mathematics to students of higher technical educational establishments, Ph.D, Institute of Information Technologies and Learning Tools of the NAES of Ukraine, 2011. (in Ukrainian)

[7] Y. Matviyiv-Lozynska, "Use of information technologies in educational extracurricular activities in higher

tourist institutions", Journal.iitta.gov.ua, 2013. [Online]. Available: https://journal.iitta.gov.ua/index.php/ itlt/article/view/801/637. Accessed on: Feb.10. 2019. (in English) 
[8] O. Martynenko, "Audiotexts' selection criteria for teaching correspondence future Interpreters listening comprehension in English", The scientific and methodological journal "Foreign Languages", 2016. [Online]. Available: http://fl.knlu.edu.ua/article/view/122572/117403. Accessed on: Feb.10.2019. (in Ukrainian)

[9] "Social Media Stats Ukraine . StatCounter Global Stats", StatCounter Global Stats, 2019. [Online]. Available: http://gs.statcounter.com/social-media-stats/all/ukraine. Accessed on: Feb.10.2019. (in English)

[10] R. Börekci and S. Aydin, "Foreign language teachers' interactions with their students on Facebook", https://www.tandfonline.com, 2019. [Online]. Available: https://www.tandfonline.com/doi/abs/10.1080/0 9588221.2018.1557691?af=R\&journalCode=ncal20. Accessed on:Feb.10. 2019. (in English)

[11] L. Yatsenko and Ya. Fabrychna, Project work as a form of extra-curricular activity for student translators and interpreters, Proceedings of 2nd International Conference on Language Research and Teaching in the Global Economic Environment, KNU, Kyiv, Ukraine, 2016, pp.81-85. (in Ukrainian)

\title{
ВИКОРИСТАННЯ ІНФОРМАЦЙНО-КОМУНІКАЦИЙНИХ ТЕХНОЛОГІЙ ДЛЯ ОРГАНІЗАЦІЇ ПОЗААУДИТОРНОЇ РОБОТИ 3 МАЙБУТНІМИ ПЕРЕКЛАДАЧАМИ
}

\author{
Ніколасва Софія Юріївна \\ доктор педагогічних наук, професор, \\ завідувачка кафедри методики викладання іноземних мов й інформаційно-комунікаційних технологій \\ Київський національний лінгвістичний університет, м. Київ, Україна \\ ORCID ID 0000-0003-2522-2059 \\ nikolaeva.ku@gmail.com
}

Шевелько Катерина Олександрівна

кандидат педагогічних наук, доцент кафедри англійської мови факультету перекладачів Київський національний лінгвістичний університет, м. Київ, Україна

ORCID ID 0000-0001-7008-843X

kateryna.shevelko@gmail.com

\section{Фабрична Яна Геннадіївна}

кандидат педагогічних наук, доцент кафедри англійської мови факультету перекладачів

Київський національний лінгвістичний університет, м. Київ, Україна

ORCID ID 0000-0003-1009-6598

yanafabrichnaya@gmail.com

\begin{abstract}
Анотація. В умовах реформування системи вищої освіти в Україні підготовка фахівців 3 теорії та практики перекладу вимагає застосування нових підходів до процесу навчання. Це потребує впровадження навчальних технологій i форм, спрямованих на активну роль студентів у вищезазначеному процесі, розвиток академічної автономності, мотивації, відповідальності та здатності студентів до самоорганізації в процесі набуття професійних знань, навичок, комунікативних умінь, формування їхнього світогляду, уміння співпрацювати з іншими студентами та викладачами на грунті взаємоповаги. Автори статті вважають, що одним із шляхів навчання іноземної мови в процесі формування загальної професійної компетентності майбутніх перекладачів може бути організація та проведення позааудиторних занять з використанням інформаційно-комунікаційних технологій.

Спираючись на результати вивчення теоретичних досліджень і практичних розробок 3 проблеми, що розглядається в статті, авторами запропоновані дві форми позааудиторних занять, описані етапи їхньої організації, цілі і завдання, проаналізовані їхня цінність й ефективність у контексті розвитку автономії і відповідальності студентів, визначені роль і функції використаних інформаційно-комунікаційних технологій.

Організація англійського розмовного клубу передбачає проведення зустрічей студентів 3 носієм англійської мови, на яких вони мають змогу практикувати використання мови, що вивчається, поза межами академічної програми. Участь в обговореннях різноманітних тем дає майбутнім перекладачам можливість удосконалювати лексичні, граматичні та
\end{abstract}


фонетичні навички, поглиблювати фонові лінгвосоціокультурні знання про англомовні країни та долати психологічні бар'єри під час говоріння англійською мовою.

Студія перекладу та озвучування функціонує у формі проєктної діяльності, що спрямована на залучення студентів до процесу перекладу різних типів англомовних аудіо i відеоматеріалів українською мовою та подальше їх озвучування. Виконуючи ролі перекладачів, коректорів, редакторів, акторів дубляжу та звукорежисерів, студенти мають можливість практично застосувати знання, комунікативні вміння та навички, яких вони набули під час академічної підготовки, зокрема вміння письмового й усного перекладу. Спеціально відібрані інформаційно-комунікаційні технології забезпечують ефективну організацію роботи розмовного клубу та студії перекладу та озвучування.

Ключові слова: позааудиторні заняття; інформаційно-комунікаційні технології; ІКТ; майбутні перекладачі

\title{
ИСПОЛЬЗОВАНИЕ ИНФОРМАЦИОННО-КОММУНИКАЦИОННЫХ ТЕХНОЛОГИЙ ДЛЯ ОРГАНИЗАЦИИ ВНЕАУДИТОРНОЙ РАБОТЫ С БУДУЩИМИ ПЕРЕВОДЧИКАМИ
}

\author{
Николаева София Юрьевна \\ доктор педагогических наук, профессор, заведующая кафедрой методики преподавания иностранных \\ языков и информационно-коммуникационных технологий \\ Киевский национальный лингвистический университет, г. Киев, Украина \\ ORCID ID 0000-0003-2522-2059 \\ nikolaeva.ku@gmail.com \\ Шевелько Екатерина Александровна \\ кандидат педагогических наук, доцент кафедры английского языка факультета переводчиков \\ Киевский национальный лингвистический университет, г. Киев, Украина \\ ORCID ID 0000-0001-7008-843X \\ kateryna.shevelko@gmail.com \\ Фабричная Яна Геннадиевна \\ кандидат педагогических наук, доцент кафедры английского языка факультета переводчиков \\ Киевский национальный лингвистический университет, г. Киев, Украина \\ ORCID ID 0000-0003-1009-6598 \\ yanafabrichnaya@gmail.com
}

\begin{abstract}
Аннотация. В условиях реформирования системы высшего образования в Украине подготовка специалистов по теории и практике перевода требует применения новых подходов к процессу обучения. Это предполагает внедрение обучающих технологий и форм, направленных на активную роль студентов в процессе приобретения профессиональных знаний, навыков, коммуникативных умений, развитие академической автономии, мотивации, ответственности и способности студентов к самоорганизации, формирование кругозора, умение сотрудничать с другими студентами и преподавателями. Авторы статьи считают, что одним из путей обучения иностранному языку в процессе формирования общей профессиональной компетентности будущих переводчиков может быть организация и проведение внеаудиторных занятий с использованием информационнокоммуникационных технологий.

Опираясь на результаты изучения теоретических исследований и практических разработок по проблеме статьи, авторы описывают две формы внеаудиторных занятий, этапы их организации, цели и задачи, анализируют их ценность и эффективность в контексте развития автономии и ответственности студентов, определяют роль и функции использованных информационно-коммуникационных технологий.

Организация английского разговорного клуба предусматривает проведение встреч студентов с носителем английского языка, на которых они могут практиковать использование изучаемого языка вне академической программы. Участие в обсуждениях различных тем дает будущим переводчикам возможность совершенствовать лексические, грамматические и фонетические навыки, углублять фоновые лингвосоциокультурные
\end{abstract}


знания про англоязычные страны, преодолевать психологические барьеры во время говорения на английском языке.

Студия перевода и озвучивания функционирует в форме проектной деятельности, направленной на привлечение студентов к процессу перевода различных типов англоязычных аудио и видеоматериалов на украинский язык и их дальнейшее озвучивание. Исполняя функции переводчиков, корректоров, редакторов, актеров дубляжа и звукорежиссеров, студенты имеют возможность применить на практике знания, коммуникативные умения и навыки, которые они приобрели во время академической подготовки, в частности умения письменного и устного перевода.

Специально отобранные информационно-коммуникационные технологии обеспечивают эффективную организацию работы разговорного клуба и студии перевода и озвучивания.

Ключевые слова: внеаудиторные занятия; информационно-коммуникационные технологии; ИКТ; будущие переводчики.

\section{(cc) $\mathrm{EY}$-NC-SA}

This work is licensed under Creative Commons Attribution-NonCommercial-ShareAlike 4.0 International License. 